\section{Effects of Repeated Yearly Application of Chemical Thinners on 'McIntosh' Apples}

\author{
Duane W. Greene ${ }^{1}$ \\ Department of Plant, Soil, and Insect Sciences, University of Massachusetts, \\ Amherst, MA 01003
}

Additional index words. Malus domestica, benzyladenine, BA, naphthaleneacetic acid, NAA, crop load, fruit quality, return bloom

\begin{abstract}
An experiment was initiated on mature 'Morespur McIntosh'on M.7 rootstock to document the effects of repeated yearly applications of benzyladenine (BA) and naphthaleneacetic acid (NAA) on fruit quality at harvest, the development of storage disorders following regular air storage, and on return bloom. When analyzed over the 4-year period, thinning did not significantly reduce crop load. This result was due in large part to no thinning response one year and very poor set on all trees in another year. Thinners were effective at increasing return bloom over the course of the experiment. BA increased fruit weight but reduced red color compared with NAA treated and control trees. Fruit quality differences at harvests were attributed primarily to crop load effects. There were no fruit quality, return bloom, or storage disorders that could not be explained by treatment effects on crop load or due to previously known effects of individual thinners. The results of this experiment clearly suggest that there are no direct adverse effects following repeated use of either NAA or BA.
\end{abstract}

Chemical thinning of apples has been practiced commercially since the early 1940 s (Dennis, 2000). The benefits and reasons for thinning are well documented (Williams and Edgerton, 1981). When bloom is heavy and conditions prior to bloom were favorable for fruit set, blossom thinners or petal fall thinner are routinely applied (Greene, 2002; Williams and Fallahi, 1999). When fruit reach 6 to 7 $\mathrm{mm}$ in diameter initial set can be estimated or quantified. If initial set is to too great, postbloom thinners are usually applied. Traditionally, thinners are not applied at this time if initial set is judged to be appropriate for the orchard.

The success or failure of a thinning program is generally assessed at harvest and observations about return bloom are made as flower clusters open the following year. Under commercial conditions untreated control trees are usually not left. Therefore, judgements about thinner response are often made without the knowledge of what would have happened if no thinner was applied.

Hundreds of chemical thinning experiments have been carried out over the past 50 years. In these chemical thinning experiments fruit set, fruit quality at harvest, postharvest behavior, and return bloom are frequently quantified. Usually, these studies span just 1 year, from thinner application at or shortly following bloom in one year to bloom the following year. If additional thinning studies are carried out, they are invariably done on different trees, due in large part to differences in bloom and flower quality that result from variable cropping the previous year.

Forshey (1982) initiated an experiment where thinning was done in the spring of year 1 and then crop load, fruit size, yield, and return bloom were followed on the same trees without

Received for publication 29 July 2004. Accepted for publication 3 Sept. 2004.

1Professor; e-mail dgreene@pssci.umass.edu. furthercrop loadadjustment overa 4-yearperiod of the study. However, this writer is unaware of any long term thinning studies done on the same trees yearly over several growing seasons. This study was initiated to document the short term and long term effects of continual application that specific thinners have on the same tree.

\section{Materials and Methods}

A block containing 40 mature 'Morespur McIntosh'/M.7 growing at the University of Massachusetts Horticultural Research Center, Belchertown, was selected. Trees were trained as a central leader and pest control and orchard management practices done according to accepted commercial practices for the region. At the pink stage of flower development two limbs per tree 10 to $15 \mathrm{~cm}$ in diameter were tagged, measured and all blossom clusters were counted. Trees were blocked into 10 groups (replications) of four trees each based upon proximity in the orchard and blossom cluster density. On 5 June 1988 when fruit size averaged 10 to $12 \mathrm{~mm}$ one tree in each block was sprayed with a hand gun dilute $50 \mathrm{mg} \cdot \mathrm{L}^{-1}$ benzyladenine (BA), a second tree in each group received $100 \mathrm{mg} \cdot \mathrm{L}^{-1} \mathrm{BA}$, and a third tree received $6 \mathrm{mg} \cdot \mathrm{L}^{-1}$ naphthaleneacetic acid (NAA). One tree in each block received no thinning spray and was considered the untreated control. At the end of June drop in July all fruit on tagged limbs were counted and final set then calculated. At the normal time of commercial harvest in September, a 30-apple sample was randomly taken from the periphery of the tree the fruit weighed and then the surface red color was estimated to the nearest $10 \%$. Ten fruit representative of the sample were selected and flesh firmness determined on two sides of each fruit using a Magness-Taylor penetrometer $(11 \mathrm{~mm}$ head). Juice was collected during the firmness test and soluble solids concentration (SSC) was determined by using a hand held refractometer on a composite juice sample. All fruit from the harvested sample were cut in half equatorially and the total number of viable seeds counted and recorded. A 20-kg storage sample was harvested from each tree and placed in regular air storage held at $0{ }^{\circ} \mathrm{C}$ for 24 weeks. Fruit were removed from storage and flesh firmness was determined on a 10-apple sample selected from the stored sample from each tree. Flesh firmness was determined as previously described. The remaining fruit were held at $20^{\circ} \mathrm{C}$ for $7 \mathrm{~d}$ and then examined for storage disorders. The following spring at the pink stage for flower development two limbs per tree were selected, the circumference measured, and total blossom clusters counted as previously described. The same thinning treatments were applied on the same trees at the 10 to $12 \mathrm{~mm}$ stage of fruit development on 31 May 1989, 31 May 1990, and 21 May 1991. Fruit set, fruit quality at harvest, postharvest fruit evaluation, and return bloom were done as previously described.

Statistical analysis was done twice using analysis of variance. The first was analysis of regression using only BA. The second analysis used all treatments where means were separated by orthogonal polynomial comparison.

\section{Results}

Over the 4-year period that this experiment was conducted there was no significant thinning treatment effect on fruit set when expressed on a limb cross sectional area basis, although year was highly significant (Table 1). NAA caused reduced fruit set relative to the control, but BA did not. When fruit set was expressed on a percent set basis all thinning treatments

Table 1. Effect of BA and NAA applied in 4 consecutive years on fruit set and return bloom of 'Morespur McIntosh'.

\begin{tabular}{|c|c|c|c|}
\hline \multirow[b]{2}{*}{$\begin{array}{l}\text { Treatment } \\
\left(\mathrm{mg} \cdot \mathrm{L}^{-1}\right)\end{array}$} & \multicolumn{2}{|c|}{ Fruit set } & \multirow{2}{*}{$\begin{array}{c}\text { Return bloom } \\
\text { Blossom clusters } \\
\text { cm limb } \\
\text { x-section area }\end{array}$} \\
\hline & $\begin{array}{c}\text { Fruit/cm } \\
\text { limb x-section } \\
\text { area }\end{array}$ & $\begin{array}{c}\text { Fruit/ } \\
100 \text { blossom } \\
\text { clusters }\end{array}$ & \\
\hline Control & 6.0 & 55 & 10.8 \\
\hline BA 50 & 5.2 & 44 & 15.1 \\
\hline BA 100 & 5.4 & 39 & 17.0 \\
\hline NAA 6 & 3.9 & 33 & 14.6 \\
\hline \multicolumn{4}{|l|}{ Significance } \\
\hline Treatment & NS & $* * *$ & $* * *$ \\
\hline BA & NS & $\mathrm{L}^{* * * *}$ & $\mathrm{~L}^{* * * *}$ \\
\hline Year & $* * *$ & $* * *$ & $* * *$ \\
\hline Treatment $\times$ year & NS & $* * *$ & $* * *$ \\
\hline Control vs. NAA & $*$ & $* * *$ & $* * *$ \\
\hline BA (50 and 100$)$ vs. NAA & NS & $* *$ & NS \\
\hline BA 50 vs. NAA & NS & $*$ & NS \\
\hline BA 100 vs. NAA & NS & NS & $*$ \\
\hline
\end{tabular}


reduced crop load, there were significant differences between years and there was a highly significant treatment $\times$ year interaction. The reasons for this interaction are complex. In 1988 NAA thinned whereas BA did not, in 1989 both BA and NAA thinned but NAA caused a treater reduction in fruit set than NAA, in 1990 BA and NAA thinned but BA thinned more severely than NAA, and in 1991 BA and NAA thinned comparably (Table 2). BA and NAA significantly increased return bloom (Table 1). The influence of year on return bloom was highly significant and there was a year $\mathrm{x}$ thinner treatment interaction. BA did not increase return bloom in 1989 , whereas NAAdid. In 1990 both BA and NAA increased return bloom. In 1991 BA had no effect on return bloom, whereas NAA reduced it, and in 1992 BA and NAA increased return bloom comparably.

Thinning treatments increased fruit weight but there was a treatment $\times$ year interaction (Table 3). In all years BA increased fruit size linearly (Table 4). The reason for the treatment $x$ year interaction is that BA increased fruit size yearly whereas NAA increased fruit size in 1988 and 1989, but reduced size in 1990 and had no effect on size in 1991. BA decreased red color whereas NAA had no effect. As one might expect, red color differed from year to year but the response to treatments was not influenced by year (Table 3 ).

BA significantly and linearly reduced flesh firmness at harvest. NAA did not affect flesh firmness. Treatments increased fruit soluble solids but there was a treatment $\times$ year interaction. In two years neither BA nor NAA affected soluble solids (Table 4). In 1989 both NAA and BA increased soluble solids, but BA caused a greater increase. NAAreduced soluble solids whereas BA had no effect in 1990. Both BA and NAA cause a small reduction in seed number. Year was significant indicating that pollination may have been different during the years of the study.

Flesh firmness was not influenced by any treatment following regular air storage for 24 weeks (Table 5). Following removal from storage fruit were kept at room temperature for $7 \mathrm{~d}$. Relative to the untreated control fruit, thinning treatments did not influence fruit decay or superficial scald. NAA reduced bitter pit and cork spot while BA had no effect. BAincreased senescent breakdown linearly.

\section{Discussion}

Frequently, orchardists agonize over the decision to thin, the thinners to use and the concentration of these thinners to apply. A conservative thinning program is often selected because of a concern for overthinning. However, it is now widely acknowledged that the response to a thinner is largely determined by weather conditions that occur after thinner application and this is generally confirmed in the results from this 4-year study. The rates of BA and NAA used in this study can be considered moderate, yet thinning relative to the untreated control occurred in only 1 year, 1989.

Fruit set in thinning trials is generally re- ported as either crop density and expressed as fruit per $\mathrm{cm}$ limb cross sectional area or as fruit set and expressed as some percentage of the initial number of blossom clusters (Lombard, et al., 1988). Both methods were reported in this paper. There was a highly significant treatment effect and a highly significant linear effect of BA on fruit set when expressed as percent set whereas there were no statistical differences when expressed as fruit per cm limb cross section area. It is generally accepted that there is an inverse relationship between bloom and final set in apples (Batjer and Billingsley, 1964; Robinson et al., 1998). Thus, heavily blooming trees set a lower percent of their flowers while light blooming trees set a high percent. Since there were highly significant differences in return bloom on these trees it appears that statistical difference in final fruit

set when expressed as percent set are largely due to differences in bloom in the spring. Therefore, expression of set as percent set in this experiment and in any others investigation where bloom is not uniform before thinner application is an inappropriate or incorrect way to report final set.

If one accepts that expression of set as fruit per centimeter limb cross-section area is the correct expression of set in this investigation, then over the 4 years, thinning treatments did not cause fruit thinning. There is a treatment $x$ year interaction. In 1988 treatments did not thin, due to weather conditions following thinner application that did not favor thinning (Greene, 2002; Robinson et al., 1998). In 1990 no thinning occur because adverse weather conditions prevailed after bloom that did not favor set thus reducing set on all trees including control trees

Table 2. Effect of BA and NAA applied in 4 consecutive years on fruit set and return bloom of 'Morespur McIntosh'.

\begin{tabular}{|c|c|c|c|}
\hline \multirow[b]{2}{*}{$\begin{array}{l}\text { Treatment } \\
\left(\mathrm{mg} \cdot \mathrm{L}^{-1}\right)\end{array}$} & \multicolumn{2}{|c|}{ Fruit set } & \multirow{2}{*}{$\begin{array}{c}\text { Return bloom } \\
\text { Blossom clusters } \\
\text { cm limb } \\
\text { x-section area }\end{array}$} \\
\hline & $\begin{array}{c}\text { Fruit } / \mathrm{cm} \\
\text { limb x-section } \\
\text { area }\end{array}$ & $\begin{array}{c}\text { Fruit/ } \\
100 \text { blossom } \\
\text { clusters }\end{array}$ & \\
\hline & \multicolumn{2}{|c|}{1988} & 1989 \\
\hline Control & 6.5 & 75 & 13.2 \\
\hline BA 50 & 6.7 & 66 & 10.7 \\
\hline BA 100 & 6.0 & 65 & 11.3 \\
\hline \multirow[t]{2}{*}{ NAA 6} & 4.4 & 48 & 15.8 \\
\hline & \multicolumn{2}{|c|}{1989} & 1990 \\
\hline Control & 10.2 & 78 & 5.8 \\
\hline BA 50 & 7.1 & 67 & 10.9 \\
\hline BA 100 & 6.0 & 59 & 15.0 \\
\hline \multirow{2}{*}{ NAA 6} & 4.5 & 29 & 12.3 \\
\hline & \multicolumn{2}{|c|}{1990} & 1991 \\
\hline Control & 1.2 & 29 & 16.7 \\
\hline BA 50 & 1.5 & 16 & 21.1 \\
\hline BA 100 & 1.5 & 10 & 18.3 \\
\hline \multirow[t]{2}{*}{ NAA 6} & 3.1 & 28 & 12.9 \\
\hline & \multicolumn{2}{|c|}{1991} & 1992 \\
\hline Control & 6.2 & 39 & 7.4 \\
\hline BA 50 & 5.4 & 26 & 17.8 \\
\hline BA 100 & 8.2 & 24 & 23.2 \\
\hline NAA 6 & 3.7 & 29 & 17.2 \\
\hline \multicolumn{4}{|l|}{ Significance } \\
\hline & \multicolumn{2}{|c|}{1988} & 1989 \\
\hline $\mathrm{BA}$ & NS & NS & NS \\
\hline Control vs. NAA & NS & $* * *$ & $* * *$ \\
\hline \multirow[t]{2}{*}{ BA vs. NAA } & NS & $* *$ & NS \\
\hline & \multicolumn{2}{|c|}{1989} & 1990 \\
\hline BA & $\mathrm{L}^{*}$ & $\mathrm{~L}^{*}$ & $\mathrm{~L}^{* * * *}$ \\
\hline Control vs. NAA & $* * *$ & $* * *$ & $* *$ \\
\hline \multirow[t]{2}{*}{ BA vs. NAA } & NS & $* *$ & NS \\
\hline & \multicolumn{2}{|c|}{1990} & 1991 \\
\hline $\mathrm{BA}$ & NS & $\mathrm{L}^{*}$ & NS \\
\hline Control vs. NAA & NS & $* * *$ & $* *$ \\
\hline \multirow[t]{2}{*}{ BA vs. NAA } & NS & $* * *$ & NS \\
\hline & \multicolumn{2}{|c|}{1991} & 1992 \\
\hline $\mathrm{BA}$ & NS & $\mathrm{L}^{*}$ & $\mathrm{~L}^{* * * *}$ \\
\hline Control vs. NAA & NS & NS & $* * *$ \\
\hline BA vs. NAA & $*$ & NS & NS \\
\hline
\end{tabular}

NS,*,*******Nonsignificant or significant at $P=0.05,0.01,0.001$, respectively; $\mathrm{L}=$ linear response.

Table 3. Effect of BA and NAA applied in 4 consecutive years on fruit quality of 'Morespur McIntosh' at harvest.

\begin{tabular}{|c|c|c|c|c|c|}
\hline $\begin{array}{l}\text { Treatment } \\
\left(\mathrm{mg} \cdot \mathrm{L}^{-1}\right)\end{array}$ & $\begin{array}{c}\text { Fruit } \\
\text { weight } \\
(\mathrm{g})\end{array}$ & $\begin{array}{l}\text { Red } \\
\text { color } \\
(\%)\end{array}$ & $\begin{array}{l}\text { Flesh } \\
\text { firmness } \\
(\mathrm{N})\end{array}$ & $\begin{array}{c}\text { Soluble } \\
\text { solids } \\
(\%)\end{array}$ & $\begin{array}{c}\text { Seed } \\
\text { no. }\end{array}$ \\
\hline Control & 152 & 60 & 67.9 & 10.7 & 7.7 \\
\hline BA 50 & 166 & 59 & 67.4 & 10.9 & 7.1 \\
\hline BA 100 & 177 & 57 & 67.4 & 11.0 & 6.8 \\
\hline NAA 6 & 163 & 60 & 67.8 & 10.8 & 6.9 \\
\hline \multicolumn{6}{|l|}{ Significance } \\
\hline Treatment & $* * *$ & $* * *$ & $* * *$ & $* * *$ & $* * *$ \\
\hline $\mathrm{BA}$ & $\mathrm{L}^{* * *}$ & $\mathrm{~L}^{* * *}$ & $\mathrm{~L}^{* *}$ & $\mathrm{~L}^{* * * *}$ & $\mathrm{~L}^{* * *}$ \\
\hline Year & $* * *$ & $* * *$ & $* * *$ & $* * *$ & $* *$ \\
\hline Treatment $\times$ year & $* * *$ & NS & NS & $* * *$ & NS \\
\hline Control vs. NAA & $* * *$ & NS & NS & NS & $* * *$ \\
\hline BA vs. NAA & $* * *$ & $* *$ & $* * *$ & $* *$ & NS \\
\hline
\end{tabular}

NS,******Nonsignificant or significant at $P=0.01,0.001$, respectively; $\mathrm{L}=$ linear response. 
Table 4. Effect of BAand NAA applied in 4 consecutive years on fruit quality of 'Morespur McIntosh' at harvest.

\begin{tabular}{|c|c|c|}
\hline $\begin{array}{l}\text { Treatment } \\
\left(\mathrm{mg} \cdot \mathrm{L}^{-1}\right)\end{array}$ & $\begin{array}{c}\text { Fruit } \\
\text { weight } \\
\text { (g) }\end{array}$ & $\begin{array}{c}\text { Soluble } \\
\text { solids } \\
(\%)\end{array}$ \\
\hline & \multicolumn{2}{|c|}{1988} \\
\hline Control & 143 & 10.7 \\
\hline BA 50 & 159 & 10.7 \\
\hline BA 100 & 170 & 11.0 \\
\hline \multirow[t]{2}{*}{ NAA 6} & 161 & 10.9 \\
\hline & \multicolumn{2}{|c|}{1989} \\
\hline Control & 133 & 10.0 \\
\hline BA 50 & 160 & 10.6 \\
\hline BA 100 & 169 & 10.7 \\
\hline \multirow[t]{2}{*}{ NAA 6} & 155 & 10.3 \\
\hline & \multicolumn{2}{|c|}{1990} \\
\hline Control & 175 & 11.1 \\
\hline BA 50 & 182 & 11.2 \\
\hline BA 100 & 194 & 11.2 \\
\hline \multirow[t]{2}{*}{ NAA 6} & 169 & 10.6 \\
\hline & \multicolumn{2}{|c|}{1991} \\
\hline Control & 155 & 11.1 \\
\hline BA 50 & 164 & 11.1 \\
\hline BA 100 & 175 & 11.2 \\
\hline NAA 6 & 168 & 11.3 \\
\hline \multicolumn{3}{|l|}{ Significance } \\
\hline & \multicolumn{2}{|c|}{1988} \\
\hline $\mathrm{BA}$ & $\mathrm{L}^{* * *}$ & NS \\
\hline Control vs. NAA & $* * *$ & NS \\
\hline \multirow{2}{*}{ BA vs. NAA } & $* * *$ & NS \\
\hline & \multicolumn{2}{|c|}{1989} \\
\hline $\mathrm{BA}$ & $\mathrm{L}^{* * *}$ & $\mathrm{~L}^{* * * *}$ \\
\hline Control vs. NAA & $* * *$ & $*$ \\
\hline \multirow[t]{2}{*}{ BA vs. NAA } & NS & $*$ \\
\hline & \multicolumn{2}{|c|}{1990} \\
\hline $\mathrm{BA}$ & $\mathrm{L}^{* * *}$ & NS \\
\hline Control vs. NAA & $* * *$ & $* * *$ \\
\hline \multirow[t]{2}{*}{ BA vs. NAA } & $* *$ & $* * *$ \\
\hline & \multicolumn{2}{|c|}{1991} \\
\hline $\mathrm{BA}$ & $\mathrm{L}^{* * * *}$ & NS \\
\hline Control vs. NAA & NS & NS \\
\hline BA vs. NAA & $* * *$ & NS \\
\hline
\end{tabular}

(Schwallier, 1996). Both BAand NAA thinned in 1989, whereas NAA reduced crop load more than BA in 1991. This experiment illustrates the varied and unpredictable nature of chemical thinning where the results are influenced by many uncontrollable factors.

One of the stated objectives of chemical thinning is to increase fruit size or weight. In all years BA increased fruit weight even though it thinned in only 1 year. It is well documented that BA can increase fruit size in the absence of thinning by increasing cell division (Wismer et al., 1995). The time of maximum cell division may vary from year to year (Al-Hinai and Roper, 2004). If the timing of BA does not coincided with the time when maximum cell division is occurring in the fruit, variable increases in fruit size may be observed. There was a highly significant treatment $x$ year interaction. Part may be explained by the differing magnitude of fruit size increase from BA. The remainder can be explained by the erratic response to NAA. In 2 years NAA increase fruit size, in one it decreased fruit size, and in 1 year it had no effect. Although increases in fruit size due to thinning by NAA are well documented in the literature, it equally well known that NAA can decrease fruit size, especially if it is applied at high concentration, if it is applied during very warm weather, or if it is applied when fruitlets are relatively large (Forshey, 1986; Greene, 2002; Williams and Edgerton, 1981).

The influence chemical thinners have on fruit soluble solids is usually manifest through the influence it exerts in modifying the fruit to leaf ratio (Forshey, 1986). In years when significant thinning occurs and there is a high leaf to fruit ratio, soluble solids will be higher. Conversely, in years when thinning does not occur or is it inadequate, the fruit to leaf ratio is lower and soluble solids are lower. There was a highly significant soluble solids $\times$ year interaction on fruit soluble solids. It appears that most of the effect can be attributed to variable crop load which is due to differences in thinning from year to year. Thus, the effect of thinners on fruit soluble solids is an indirect effect rather than a direct effect.

One of the major reasons to chemically thin apples is to ensure adequate return bloom (Batjer and Billingsley, 1964; Williams and Edgerton, 1981). In this investigation, adequate and in most cases, heavy return bloom was recorded on all NAA and BA treated trees. NAA has been reported to increase flowing beyond that which can be explained directly by the reduction in crop load (Harley et al., 1958). This observation has lead to the recommendation in some regions to augment flowering on apples in some years by applying NAA several times at low rates at the end of the thinning season(New England Pest Management Guide, 2003). There have been no reports that BA enhances flowering beyond that directly attributed to reduced crop load due to thinning. In this investigation BA and NAA enhanced flowering comparably in all years

The effects of BAand NAA on development of storage disorders were generally small, and

Table 5. Effect of BA and NAA applied in 4 consecutive years on flesh firmness and storage disorders of 'Morespur McIntosh' following 24 weeks of air storage.

\begin{tabular}{|c|c|c|c|c|c|}
\hline $\begin{array}{l}\text { Treatment } \\
\left(\mathrm{mg} \cdot \mathrm{L}^{-1}\right)\end{array}$ & $\begin{array}{c}\text { Flesh } \\
\text { firmness } \\
(\mathrm{N})\end{array}$ & $\begin{array}{c}\text { Senescent } \\
\text { breakdown } \\
(\%)\end{array}$ & $\begin{array}{c}\text { Fruit } \\
\text { decay } \\
(\%)\end{array}$ & $\begin{array}{l}\text { Superficial } \\
\text { scald } \\
(\%)\end{array}$ & $\begin{array}{l}\text { Bitter pit \% } \\
\text { cork spot } \\
(\%)\end{array}$ \\
\hline Control & 39.4 & 10 & 18 & 15 & 5 \\
\hline BA 50 & 39.4 & 13 & 18 & 15 & 3 \\
\hline BA 100 & 39.0 & 15 & 20 & 13 & 5 \\
\hline NAA 6 & 39.4 & 8 & 16 & 13 & 1 \\
\hline \multicolumn{6}{|l|}{ Significance } \\
\hline Treatment & NS & $* * *$ & NS & NS & $*$ \\
\hline $\mathrm{BA}$ & NS & $\mathrm{L}^{*}$ & NS & NS & NS \\
\hline Year & $* * *$ & $* * *$ & $* * *$ & $* * *$ & $* * *$ \\
\hline Treatment $\times$ year & NS & NS & NS & NS & NS \\
\hline Control vs. NAA & NS & NS & NS & NS & $* *$ \\
\hline BA (50 and 100$)$ vs. NAA & NS & $* * *$ & $*$ & NS & NS \\
\hline BA 50 vs. NAA & NS & $* *$ & NS & NS & NS \\
\hline BA 100 vs. NAA & NS & $* * *$ & $*$ & NS & * \\
\hline
\end{tabular}

NS,***,***NNonsignificant or significant at $P=0.05,0.01,0.001$, respectively; $\mathrm{L}=$ linear response. where significant, appear to be associated with secondary effects. BA increased senescent breakdown after storage. These fruit were larger and undoubtedly had lower calcium concentration in the flesh. It is well documented that there is an inverse relations between senescent breakdown and fruit flesh calcium (Shear, 1975). This is in agreement with the report by Elfving and Loughheed, 1994).

During this 4-year study the same thinning treatments were applied to the same trees each year. There were no fruit quality, return bloom, or storage disorder results that could not be explained by treatment effect on crop load or due to known effects of individual thinners. Therefore, the results of this experiment clearly suggest that orchardist need not be concerned about cumulative negative effects following repeated yearly applications of NAA or BA. Further, these data support the concept that weather can dictate the success or failure of attempts to control physiological processes with plant growth regulators.

\section{Literature Cited}

Al-Hinai, Y.K. and T.L. Roper. 2004. Rootstock effects on growth, cell number, and cell size of 'Gala' apples. J. Amer. Soc. Hort. Sci. 129:37-41

Batjer, L.P. And H.D. Billingsley. 1964. Apple thinning with chemical sprays. Wash. State Agr. Expt. Station Bul. 651.

Dennis, F.G. 2000. The history of fruit thinning. Plant Growth Regulat. 31:1-16.

Elfving, D.C. and E.C. Louoghheed. 1994. Storage response of 'Empire' apples to benzyladenine and other chemical thinners. J. Amer. Soc. Hort. Sci. 199:253-257.

Forshey, C.G. 1982. Effects of fruiting, pruning, and nitrogen fertilization on shoot growth of 'Empire' apple trees. J. Amer. Soc. Hort. Sci. 107:1092-1097.

Forshey, C.G. 1986. Chemical fruit thinning of apples. N.Y. Food and Life Sci. Bul. 116.

Greene, D.W. 2002. Chemicals, timing, and environmental factors involved in thinner efficacy on apple. HortScience 37:477-481.

Harley, C.P., H.H. Moon, and L.O. Regeimbal. 1958. Evidence the post-bloom apple-thinning sprays of naphthaleneacetic acid increase blossom-bud formation. Proc. Amer. Soc. Hort. Sci. 72:52-56.

Lombard,P.B., N.W.Callan, F.G.Dennis, N.E.Looney, G.C.Martin,A.R. Renquist, andE.A. Mielke. 1988. Towards a standardized nomenclature, procedures, values, and units in determining fruit and nut tree yield performance. HortScience 23:813-817.

New England Pest Managment Guide. 2003. W. Coli (ed.).Univ.Conn,-Univ. Maine-Univ.Mass--Univ. N.H.-Univ. R.I.-Univ. Vt. Coop. Ext.

Robinson, T.L., A.N. Lakso, E. Stover, and S. Hoying. Practical thinning programs for New York. N.Y. Fruit Quart. 6(1):14-18.

Schwailler, P.G. 1996. Apple thinning guide. Great Lakes Publ. Co., Sparta, Mich.

Shear, C.B. 1975. Calcium-related disorders of fruit and vegetables. HortScience 10:361-365.

Williams, K.M. and E. Fallahi. 1999. The effects of exogenous bioregulators and environment on regular cropping of apple. HortTechnology 9:323-327.

Williams, M.W. and L.J. Edgerton. 1981. Fruit thinning of apples and pears with chemicals. USDA Agr. Info. Bul. 289.

Wismer, P.T., J.T.A. Proctor, and D.C. Elfving. 1995. Benzyladenine affects cell division and cell size during apple fruit thinning. J. Amer. Soc. Hort. Sci. 120:802-807. 